Preliminary, not to be quoted

\title{
Financial Stability in European Banking: The Role of Common Factors
}

\author{
Clemens J.M. Kool* \\ Utrecht School of Economics \\ Utrecht University, the Netherlands
}

March 2006

\begin{abstract}
:
In this paper, I investigate the development and determinants of CDS spreads for 18 major European banks between December 2001 and January 2004 using daily data. I demonstrate that two nonstationary common factors can be extracted from the data that together explain most CDS spread variation across time and across banks. The group of German banks plus a few SouthernEuropean banks appear to systematically have high CDS spreads and to be relatively sensitive to changes in the underlying factors. The dominating first common factor impacts on all banks in a similar direction, suggesting strong market integration. However, the quantitatively less important second factor has opposite effects on credit spreads of Southern European versus Northern European banks, suggesting some remaining country-specific or region-specific credit risk. Finally, I show that the first common factor may indeed be interpreted as a measure of market conditions as it is cointegrated with the European $\mathrm{P} / \mathrm{E}$ ratio and the 2-year nominal interest rate.
\end{abstract}

* Clemens J.M. Kool is professor of Finance and Financial Markets at the Utrecht School of Economics, Utrecht University, the Netherlands [postal address Vredenburg 138, 3511 BG Utrecht, the Netherlands; email c.kool@econ.uu.nl]. The paper was prepared for the Conference "Perspectives on Monetary, Financial, and Economic Integration”, April 7-8, 2006 at the Kelley School of Business, Indiana University in honour of Michele Fratianni. The paper is an extension of previous work with Matthias Klein who also prepared the data. I'd like to thank him for his significant contribution. Any remaining errors are my own. 


\section{Introduction}

An efficient and stable financial system is a crucial ingredient for economic development and growth. A broad consensus exists in the literature that such a system contributes to an efficient allocation of real economic resources across time and space and an efficient management of wealth and capital accumulation. In most developed countries, banks besides financial markets - play a crucial role as intermediary institutions in the process of asset allocation. Correspondingly, the efficiency and stability of the banking system is a crucial concern for monetary and supervisory authorities.

An important issue in this respect is how and to what extent a trade-off exists between efficiency on the one hand and stability on the other. Focusing on the banking sector, market entry and exit should be a normal phenomenon as in any other industry. That is, competition between banks should be encouraged to allow the market as a whole to become more efficient. In the European context, this was the major goal of the creation of the common market for financial products and services in the early 1990s. As a result, banks from any EU country can operate now throughout the EU with a single banking licence. Financial integration was hypothesized to result in more competition and higher efficiency. Obviously, individual under-performing banks then can default in the process.

However, the occurrence of outright bank failure in the European financial system is a rare event. Nevertheless, the recent past has shown a number of situations when financial markets seem to have been considerably preoccupied by the financial soundness of several European banks. ${ }^{1}$ Situations of systemic financial distress remain a concrete threat to both markets and supervisory authorities. Although the default of an individual bank is not the issue here, the risk of contagion makes both markets and supervisory authorities wary of such events. As a result, supervision on a micro-level is used to promote financial stability and to avoid systemic macro-instability. ${ }^{2}$

Given the importance of systemic financial stability and the possible relation between individual bank's fragility to economic shocks and the system's overall

\footnotetext{
${ }^{1}$ See for example Financial Times, 14 October 2002, "Bad debts, falling capital, dismal profits"

${ }^{2}$ The precise definition of financial stability is still subject of debate. Padoa-Schioppa (2003) provides a rather broad and general definition of financial stability as "a condition where the financial system is able to withstand shocks without giving way to cumulative processes which impair the allocation of savings to investment opportunities and the processing of payment in the economy."
} 
vulnerability, appropriate measurement of individual banks' financial risk is crucial both for investors and other market participants and supervisory authorities. Higher financial integration and stronger (cross-country) competition only serve to increase the importance of financial stability analysis. Traditionally, financial stability analysis of individual financial institutions consisted of regular on-site inspections of banks by regulatory authorities and the analysis of financial accounting ratios. In recent years, however, the use of market-based risk measures has considerably gained popularity. Technological progress in combination with new financial instruments facilitates economic and financial risk management in a globally integrated economic system by pricing, repackaging and transferring risks. The corresponding availability of low-cost and high-frequency market data on for instance subordinated debt spreads, equity prices and equity returns have significantly contributed to their use in financial stability analysis. In addition, the reliability and information content of traditional accounting measures is increasingly questioned.

A relatively new financial instrument to transfer and price credit risk is the credit default swap (CDS). CDS offer protection on default of a credit, comparable to credit insurance, by requiring a regular fee to be paid, the premium or CDS spread, in exchange for compensation in case of default. CDS spreads are increasingly accepted as appropriate measures of individual bank's credit risk. In this paper, I investigate the development and determinants of CDS spreads for 18 major European banks between December 2001 and January 2004 using daily data. More particularly, spreads are decomposed into one or more common factors and idiosyncratic determinants. Assuming that the CDS market appropriately prices each bank's riskiness into the CDS spreads, differences between banks may arise from two sources. On the one hand, a bank's risk level may be affected by a common (market) shock differently from other banks due to different underlying characteristics. On the other hand a bank's risk level may change due to "own" shocks that do not influence the market as a whole.

I demonstrate that two nonstationary common factors can be extracted from the data that together explain most CDS spread variation across time and across banks. The group of German banks plus a few Southern-European banks appear to systematically have high CDS spreads and to be relatively sensitive to changes in the underlying factors. 
The dominating first common factor impacts on all banks in a similar direction, suggesting strong market integration. However, the quantitatively less important second factor has opposite effects on credit spreads of Southern European versus Northern European banks, suggesting some remaining country-specific or region-specific credit risk. Finally, I show that the first common factor may indeed be interpreted as a measure of market conditions as it is cointegrated with the European $\mathrm{P} / \mathrm{E}$ ratio and the 2-year nominal interest rate.

The paper is set up as follows. In section 2, I briefly discuss the literature with respect to the use of market indicators of financial risk. In section 3 I present CDS spread data and the proposed research methodology, while empirical results are presented and discussed in section 4 . In section 5 I elaborate on the link between the observed common factor in CDS spreads and two aggregate financial variables, the European $\mathrm{P} / \mathrm{E}$ ratio and the European 2-year interest rate. Section 6 concludes.

\section{Market indicators of financial stability}

The idea to complement the traditional supervisory approach with market data has received growing attention, both in academic research and practical supervision. Market indicators of financial stability should react to any change in the underlying risk profile which they measure, be it risk specific to one bank (idiosyncratic risk), or common to all banks in the market (systemic risk). In practice, however, this strict distinction between individual risks and systemic risks is more difficult to maintain in the modern banking system. Banks operate more and more on an international basis, the traditional boundaries between activities such as commercial banking, insurance and investment banking are disappearing and interaction, hence mutual exposure between individual institutions, national markets and different types of financial institutions is rising. The increase of mutual exposure in combination with high volatility of asset markets as well as international payment and security settlement systems provides an ideal structure for the propagation of contagion effects. ${ }^{3}$ That is, a shock to one financial institution may spread through the global system and affect other banks' (perceived and actual) riskiness as well.

\footnotetext{
${ }^{3}$ See Hartmann and de Brandt (2000).
} 
Alternatively, situations of distress may stem from negative shocks to market conditions that in turn simultaneously but differentially affect implicit credit risk of individual banks. In principle, any market-based indicator of an individual bank's riskiness should include both the riskiness associated with direct shocks in its own operations and with indirect shocks to market conditions that subsequently impact on the bank's operations and position.

Initially, research with respect to market indicators of credit risk focused on subordinated debt (SND) issued by financial institutions, see Gilbert (1990) for an early analysis. The use of subordinated debt is motivated by the higher risk-sensitivity of such more junior debt, since any increase in risk should first translate into higher spreads for the more junior debt tranches. Most importantly, the asymmetric payoff of debt instruments motivates its use for supervisory purposes, as it creates similar interests for bond investors and supervisors. Investors are exposed to all downside risk but do not profit from upside-gains following increased risk-taking and consequently, spreads react to increases in risk but behave neutrally to upside gains, unlike equity. Gropp, Vesala and Vulpes (2002) provide proof of the theoretical properties of the SND indicator and derive a pricing formula for subordinated debt, which depends on asset value, leverage and asset volatility.

By now, bank subordinated debt has become a standard indicator in financial stability analysis. Flannery and Sorescu (1996) find that subordinated debt spreads overall reflect bank risk as measured by financial accounting ratios. However, this only holds in the absence of government guarantees to bail out banks. Recently, Birchler and Hancock (2004) argue that subordinated bond spreads may be distorted by other factors such as poor market liquidity or fluctuations in the price of market risk in some circumstances. Elton, Gruber, Agrawal and Mann (2001) and Hancock and Kwast (2001) point out additional potential problems with using subordinated debt spreads as expected loss indicators to investors.

Extending the analysis to the equity market, Krainer and Lopez (2002) find that equity data, in particular stock returns and estimated distance to default (EDF), are also viable risk indicators for banks. Swidler and Wilcox (2002) broaden the set of assets to include equity options. They demonstrate that implied volatility is a good predictor of 
future realized volatility and deduce it, thus, also has a signalling function for bank risk. Pointing to the low costs and high-frequency availability of such data, Swidler and Wilcox strongly encourage the use of implied volatility measures for supervisory purposes. Note that implied equity volatility is the main input to another frequently used measure of financial stability, distance to default, and is its main driver in the short-run.

Gropp, Vesala and Vulpes (2002) present a comparison of an equity-based indicator (distance to default) and a bond-market related indicator (subordinated debt spreads). They suggest a complimentary use of both equity and bond-indicators, potentially in conjunction with other market or accounting data. Berger, Davies and Flannery (2000) provide a similar comparison. They conclude that supervisory assessments are much more closely tied to bond ratings than to equity market assessments. However, supervisory ratings have a much stronger contemporaneous focus than forward-looking market indicators. Also, the time-value of supervisory information declines and considerable private knowledge is only present immediately after an inspection and looses its exclusiveness rather quickly. DeYoung, Flannery, Lang and Sorescu (2001) arrive at a similar conclusion. Berger et al. (2000), therefore, conclude: "supervisors, bond market participants and equity market participants all produce valuable, complimentary information which may contribute to improving the governance of large banking organizations".

Recently, CDS spreads have become increasingly popular as direct and easy indicator of a firm's credit risk. Theoretically, the structure of a CDS deal gives it a clear advantage over other assets, most importantly corporate bonds, in assessing a firm's credit risk profile. Because CDS' payoff-scheme is strictly limited to situations of default, CDS spreads are a direct measure of default risk. On the other hand, inferring default risk from corporate bonds necessitates a number of complicating assumptions and calculations. For instance, to extract an appropriate credit risk measure from the corporate bond rate, an appropriate risk free rate needs to be defined and account should be taken of other determinants of the bond spread such as incorporated put or call options. Research on CDS spreads is still limited, mostly because the CDS market has only gained a substantial size since the early 2000s. All studies are subject to the criticism of relatively low time-series and/or cross-section dimensions. Most empirical studies so far focus on 
the pricing characteristics of CDS spreads. Examples are Norden and Weber (2004), Zhu (2004), Longstaff, Mithal and Neis (2004), Cossin and Lu (2004), and Blanco, Brennan and Marsh (2004). The general consensus in these studies is that CDS spreads do indeed price credit risk efficiently. ${ }^{4}$ Both Blanco et al. (2004) and Norden and Weber (2004) conclude that for most firms in their sample an equilibrium parity condition holds between CDS spreads and bond spreads, where the CDS market leads the bond market with respect to price discovery. Deviations from parity do exist for some firms, however. Longstaff, Mithal and Neis (2004) also find a pricing differential between the CDS and the corporate bond market for some firms and demonstrate that illiquidity in the bond market is the most likely reason for the observed difference in spreads. Cossin and Lu (2004) point to liquidity premiums, cheapest-to-deliver options and market segmentation to explain price differences. Zhu (2004) uses a VECM approach to examine the relative importance of the two markets and comes to similar conclusions.

Few studies exist that investigate the determinants of CDS spreads. Exceptions are Aunon-Nerin et al. (2002) and Ericsson et al. (2005). Aunon-Nerin et al. (2002) use both firm-specific information and market information to explain CDS spreads. Significant firm-specific drivers of CDS spreads are its rating, asset volatility, stock price change, leverage and market capitalization. In addition, a higher money market interest rate supposedly capturing a positive macro-economic outlook - reduced CDS spreads significantly. Ericsson et al. (2005) provide similar evidence that firm leverage, volatility and the riskless interest rate explain a significant amount of variation in the data. This paper is related to Aunon-Nerin et al. (2002) and Ericsson et al. (2005) in that it investigates determinants of CDS spreads. However, both the focus and the approach taken are somewhat different. With respect to the focus of the paper, I only consider banks, while most other studies have a mix of industrial and financial firms. Concerning the approach taken, I first decompose the overall variation in spreads into common factors and residual (idiosyncratic) noise. Second, each firm's sensitivity to changes in these common factors is investigated. Finally, I show that the first common factor that

\footnotetext{
${ }^{4}$ Houweling and Vorst (2001) point out that the precision of the pricing procedure depends on the rating of the underlying entity. Spreads for high-rated firms are more precise than those for lower-rated firms. Hull, Predescu and White (2004) support this finding and explain it by counter party default risk of CDS and a liquidity premium on the issuer's bonds.
} 
explains the majority of CDS variation can be interpreted as an overall indicator of market conditions.

\section{Data description and methodology}

\section{Sample banks}

The sample consists of 18 major European banks. Table 1 lists the set of financial institutions included in the analysis ranked in terms of assets as of early 2004. It includes all top-10 European banks. In addition, 16 out of the 18 banks are top-5 banks in their respective national market. It is thus reasonable to claim that the sample provides a fair coverage of the European banking market in spite of its small size. Note that the largest banks are particular interest due to their relatively higher contagion potential.

\section{Sample period}

The time-period examined runs from December 2001 to January 2004. Data are averages of bid and ask quotes taken from CreditTrade. CDS spreads offer protection against junior (subordinated debt). For two banks - notably the Spanish banks BBVA and BSCH CDS daily data start in May 2001. Only from December 2001 onward, CDS spreads are available for all 18 banks. In addition, occasionally data are missing for specific days and banks. Throughout the analysis, I use a balanced panel of daily data consisting of 532 observations.

In table 2, I report stylised statistics for the CDS spreads per bank. Spreads are reported in basis points. Panel A contains information on the level of the spreads, while panel B has corresponding information on spread changes. Most banks experienced a mean spread of 40 to 50 basis points over the period, as shown in panel A. Exceptions are Bayerische Hypo and Commerz Bank with a mean spread of about 136 basis points and $\mathrm{BSCH}$, Intesa and Dresdner with a spread of about 70 to 80 basis points. Standard deviations for most banks are around 10-20 basis points. Commerz has the highest standard deviation equal to 88 basis points. Generally, mean spreads and standard deviations appear positively correlated. Panel B shows that CDS spreads had no significant trend over the sample. Mean changes are all quite close to zero, especially when compared to their standard deviations. The majority of banks have a daily standard 
deviation of at most 5 basis points. Only for Commerz and Bayerische Hypo the standard deviation exceeds 10 basis points.

In figure 1, I graphically show the development of the CDS spreads over the sample period, split out per country. Spreads are relatively stable over 2001 and the first half of 2002. From the middle of 2002 till around October/November there is a run-up in spreads for most banks, though in different degrees. Subsequently, spreads gradually decline with a new hike in early 2003 for a subset of banks. By the end of the sample, spreads typically have declined to levels similar to or even lower than the levels prevailing in 2001. Note that there seems to be considerable variation in spreads both within countries and across countries. Unreported results show that the existence of a unit root cannot be rejected for any of the CDS spreads. The first difference series are all stationary. $^{5}$

\section{Methodology}

It is the purpose of the exploratory analysis to decompose CDS spreads across banks into one or more common factors - to which banks can respond differently -- and idiosyncratic factors, attributable to one banks or possibly a small group of banks. Due to the non-stationary properties of the input data, I use the method proposed by Stock and Watson (1988) and Gonzalo and Granger (1995) to extract common factors or trends corresponding to the latent risk dimensions in the data ${ }^{6}$.

Stock and Watson (1988) show that if a vector $\mathrm{X}_{\mathrm{t}}$ is cointegrated, a common factor representation exists of the form

(1) $\quad X_{t}=A_{1} f_{t}+\tilde{X}_{t}$

Thus, if $X_{t}$ is a (px1) vector of $\mathrm{I}(1)$ series with cointegration rank $r$, then the elements of $X_{t}$ can be explained in terms of a smaller number of $(p-r) I(1)$ variables, $f_{t}$, called

\footnotetext{
${ }^{5}$ Results are based on ADF tests and are available from the author on request. Despite the substantial number of observations, the results have to be interpreted with caution due to the short calendar time (slightly over two years of data). Longer time series are needed for more reliable inferences regarding nonstationarity.

${ }^{6}$ Conventional multivariate factor analysis is theoretically inappropriate as the underlying assumption of stationarity does not hold. The alternative of first-differencing the data would result in a loss of information with respect to the data's level-dynamics.
} 
common factors plus some $\mathrm{I}(0)$ components, $\widetilde{X}_{t}$. Gonzalo and Granger (1995) present a procedure for extracting the common factors, by imposing two identifying assumptions:

1) $f_{t}$ are linear combinations of $X_{t}$, allowing to associate the common factors with the observable variables,

2) $\mathrm{A}_{1} \mathrm{f}_{\mathrm{t}}$ and $\widetilde{X}_{t}$ form a P-T (permanent-transitory) decomposition, implying that the common factors summarise the long-run behaviour of the original variables.

On the basis of this, the factor model $X_{t}=A_{1} f_{t}+\widetilde{X}_{t}$ can be rewritten as $\mathrm{X}_{\mathrm{t}}=\mathrm{A}_{1} \mathrm{f}_{\mathrm{t}}+\mathrm{A}_{2}$ $\mathrm{z}_{\mathrm{t}}$, where $f_{t}=\gamma_{\perp} X_{t}, z_{t}=\alpha^{\prime} X_{t}$ and $\widetilde{X}_{t}=A_{2} a^{\prime} X_{t}=A_{2} z_{t}$. The routine to extract the factors $\mathrm{f}_{\mathrm{t}}$ is largely based on the cointegration test proposed by Johansen and Juselius (1990). Estimates for $\gamma_{\perp}$ and $\alpha^{\prime}$ are obtained by regressing $\Delta \mathrm{X}_{\mathrm{t}}$ and $\mathrm{X}_{\mathrm{t}-1}$ on $\left(\Delta \mathrm{X}_{\mathrm{t}-1}, \ldots, \Delta \mathrm{X}_{\mathrm{t}-\mathrm{q}+1}\right)$, providing residuals $\mathrm{R}_{0 \mathrm{t}}$ and $\mathrm{R}_{1 \mathrm{t}}$. From the residuals the product moment matrix $S_{i j}=T^{-1} \sum_{t=1}^{T} R_{i t} R^{\prime}{ }_{j t} \mathrm{i}, \mathrm{j}=0,1$ is formed. Subsequently, solving the equations $\left|\lambda S_{11}-S_{10} S_{00}{ }^{-1} S_{01}\right|=0$ and $\left|\lambda S_{00}-S_{01} S_{11}{ }^{-1} S_{10}\right|=0$ yields eigenvalues and their corresponding eigenvectors $\mathrm{V}$ and $\mathrm{M}$, from which estimates of $\alpha^{\prime}$ and $\gamma_{\perp}$ are obtained.

In practice, the analysis by Gonzalo and Granger consists of a cointegration test in order to determine the number of underlying common trends/factors in the data. The common trends are then extracted from the data in a second step. This routine becomes problematic, however, when high dimensionality datasets have to be examined, for which standard tests of cointegration cannot be implemented. ${ }^{7}$ This is also the case at hand.

In order to circumvent this problem, Gonzalo and Granger show that it is possible to analyse a set of variables in (logical) smaller subsystems. The authors demonstrate that combining the analysis of two separate subsystems yields identical results as an analysis of the entire system ${ }^{8}$. In the present case, in order to handle the dimension of $18 \mathrm{CDS}$

\footnotetext{
${ }^{7}$ Critical values for the cointegration rank, $r$, are not available for $r>10$ in standard tests.

${ }^{8}$ Granger and Haldrup (1997) point out some theoretical limitations of this procedure. They show that if the condition of (complete) separation between the time series in the two subsystems is not met, there is a risk of obtaining biased results. To mitigate this risk in practice, the common factors are both estimated using the entire system (based on the number of common factors determined beforehand) and using the subsystems. Both types of analysis yield equivalent results. Also the test of the cointegration rank in the
} 
spreads (banks), the data are split into two subsystems, each containing the data of 9 banks. Subsequently, a factor analysis is carried out for the two subsystems separately in a first step, resulting in a set of I (1) common factors for each subsystem. In the second step, a cointegration test on these common factors (extracted from the two subsystems) can then determine the number of common trends/factors for the entire system. Obtaining an estimate of the common factors for the entire system is possible since the common factors between the I (1) factors of the two subsystems will be the factors driving the whole system of variables in the long run, i.e. the common trends underlying the data of each indicator, according to Gonzalo and Granger. Stated differently, the common factors of the two subsystems contain the aggregated information on the underlying dimensions of the two subsystems. Combining these common factors in a second common factor analysis merges this information and yields a new set of common factors that capture the underlying dimension of the entire dataset (for each indicator).

By means of this procedure, a decomposition of the data into a common (nonstationary) and a specific (stationary) dimension can be achieved - reflecting the common and specific risk level. The extracted common trends capture the common long-run characteristics of the banks' time series and reflect the latent dimension(s) that underlie the data. It is expected to yield a decomposition of the risk captured by the indicators into a common (systemic) and a bank-specific (idiosyncratic) dimension and should thus permit an analysis of the forces driving risk (and return) of CDS spreads.

\section{Results}

Using the procedure described above yields two non-stationary common factors/trends for the CDS spreads. ${ }^{9}$ In figure 2, both factors - standardized at a mean of zero and a standard deviation of one - are presented. The first factor captures the general pattern that is present in all CDS spreads across banks. It accounts for 88 percent of total variation in the system. Factor loadings for individual banks are invariably very high. Apart from

subsystems is repeated using different combinations of banks in the subsystems. This does not affect the results. Overall, I feel confident that the procedure proposed by Gonzalo and Granger is valid here.

${ }^{9}$ Unreported unit ADF root tests do not reject the unit root in these series. 
three German banks - Bayerische Hypo, Commerz and Dresdner - these are above 0.90. One might interpret this as the overall market factor. ${ }^{10}$ The second factor that only explains about 7 percent of total variation has quite different characteristics. It has a trough in 2002 and a peak in the first half of 2003. All German and UK banks plus the Dutch ING load positively on this factor, while all French, Spanish, Italian and Swiss banks plus the Dutch ABN Amro load negatively. Broadly speaking, it suggests a difference in risk behaviour between banks in Southern Europe as compared to Northern Europe.

The simple level regressions in Table 3 confirm the story. In the table, White's heteroskedasticity-consistent standard errors are in parentheses. Note that JohansenJuselius cointegration tests indicate cointegration between the two common factors and each individual bank's CDS spread. ${ }^{11}$ The regressions therefore may also be interpreted as cointegration vectors.

A few important observations stand out. First, for most banks the coefficient on the first factor is between 10 and 20. For six banks, a considerable higher sensitivity is estimated. This is the case for all four German banks - though to a different degree - plus the Italian Intesa bank and the Spanish BSCH. Note that the German banks, together with Intesa and $\mathrm{BSCH}$ also have the highest average spreads over the sample period. Second, apart from the geographical pattern in coefficients for the second factor that has already been discussed, coefficients on the second factor are especially large and positive for all German banks apart from Deutsche Bank, and relatively large and negative for the two Spanish banks BBVA and BSCH. Note that the German banks, together with Intesa and $\mathrm{BSCH}$ also have the highest average spread over the sample period.

Overall, the results suggest that the market as a whole largely moves together. That is, overall market conditions appear to be the main driver of the required credit risk premium for each bank. No evidence is found for the existence and importance of major idiosyncratic events (shocks) that influence individual banks' credit risk. On the other

\footnotetext{
${ }^{10}$ Obviously, in light of the small size of the sample, the term "market risk factor" has to be used with caution. However, with 20 large European banks in the sample, it nonetheless captures a reasonable share of the European market. The term "market risk factor" will thus continue to be used.

${ }^{11}$ Given the construction of the factors, this is not surprising. Alternatively, I performed a standard principal components analysis. The first two principal components are virtually the same as the two common factors and are non-stationary. The next four principal components are all stationary.
} 
hand, it is true that banks differ in the level and volatility of the required risk premium. Especially the German banks and some Spanish and Italian banks have a substantially higher average CDS spread and a substantially higher sensitivity of the required spread with respect to changes in market conditions than the other banks in the sample. Finally, a second - quantitatively less important - factor driving credit spreads distinguishes between Northern European (UK and Germany) and Southern European (Spain, Italy, France and Switzerland) banks. The evidence for Dutch banks is mixed in this respect.

On the one hand, the evidence strongly suggest that the European banking has become quite integrated, especially for the group of major international banks that is considered in this analysis. Overall European market conditions that may be captured in the first common factor are the dominant factor behind changes in credit risk. On the other hand, significant differences exist in the degree to which individual banks'credit risk premium respond to these market conditions. Here, a country dimension seems to be present. Especially the large German banks are more sensitive to the overall common factor than banks from other countries. The existence of a second nonstationary common trend that roughly separates Southern European from Northern European banks is an additional indication of incomplete market integration.

In Table 4, I report additional evidence on the dynamics of changes in credit spreads. For each bank the change in the spread has been regressed on the contemporaneous changes in the first factors and the (unrestricted) lagged levels. The regression has the following form:

$$
\Delta \mathrm{cds}=\alpha_{0}+\alpha_{1} \Delta \text { factor } 1+\alpha_{2} \Delta \text { factor } 2+\alpha_{3}\left(\operatorname{cds}_{-1}-\alpha_{4} \text { factor } 1_{-1}-\alpha_{5} \text { factor } 2_{-1}\right)
$$

where $\Delta$ represent the first difference operator, cds is the spread for an individual bank and factor 1 and factor 2 are the two extracted common factors. This allows the estimation of the speed of mean reversion $\left(\alpha_{3}\right)$ in credit spreads to their long-run trend. The overall evidence is consistent with table 3. Sign and magnitude of the coefficients corresponding to the lagged level of the common factors in table 4 is close to those in the cointegration regressions in table 3 . The error correction coefficient $\left(\alpha_{3}\right)$ is around -0.10 for most banks, suggesting that about 10 percent of a deviation from the long-run 
equilibrium relation is corrected in one day. In most cases, the effect of a contemporaneous change in one of the factors on the spread is of the same order of magnitude as the long-run effect. This suggests that the gap between the long run credit spread level as determined by the nonstationary common factors and the actual spread may be primarily driven by stationary firm-specific factors.

\section{What's Behind the First Common Factor?}

In the discussion so far, I have assumed that the first common factor essentially captures overall market conditions. I primarily based this assumption on the consistently high positive loading of each and every individual bank's CDS spread on the factor. It is hard to imagine how a series of independent idiosyncratic shocks originating from different banks could lead to such synchronized behaviour of all banks in the market. In this section, I explicitly investigate whether it is possible to link the first common factor to a number of exogenous aggregate economic variables. This allows a closer analysis of the market risk factors and potential identification of the forces driving market risk. Due to the relatively short sample-period, the variables used for this purpose need to have a daily frequency, corresponding to the CDS spread data. This leaves only financial variables as potential candidates. In the subsequent analysis, I use three key aggregate financial variables ${ }^{12}$ :

- the Euro-Area 2 year nominal interest rate

- the P/E ratio of the DataStream European Equity market index

In a first pass through these data, I perform unit root tests on the two individual series. For neither of these series the unit root is rejected. Subsequently, I perform a JohansenJuselius cointegration test between the first common factor and the above two aggegrate financial series. The Max-eigenvalue test indicates 1 cointegrating equation at both the $5 \%$ and $1 \%$ levels with normalized cointegrating coefficients of 0.83 (standard error 0.07 ) for the $\mathrm{P} / \mathrm{E}$ ratio and -1.80 (standard error 0.20 ) for the nominal 2-year interest rate. That

\footnotetext{
${ }^{12}$ All variables are taken from Datastream. Using 3 month rates, and 2-year and 10 year bond rates, I experimented with different combinations of yield curves and interest rate levels to be included in the analysis. The results are qualitatively invariant to the choice of variables.
} 
is high European price earning ratios reduce the CDS spreads, while a high nominal interest rate increases the CDS spread for all banks. Note that the direction of the interest rate effect is opposite to the one found by Aunon-Nerin et al. (2002).

A corresponding cointegration test between the second common factor and the $\mathrm{P} / \mathrm{E}$ ratio and the nominal 2-year interest rate did not indicate a cointegrating relation between these three variables. It suggests that more research is required to determine the drivers behind the second common factor (that split the group of European banks roughly in two different groups).

Overall, the evidence supports the interpretation of the first common factor as an indicator of overall market conditions.

\section{Conclusion}

Financial stability is a major concern for market participants and supervisory authorities alike. Banks play a major role in the global financial system and have become more interconnected over the last decades, due to deregulation, liberalization and technological progress. The creation of the internal European market for the purpose of higher competition and efficiency has added to these developments. However, it has also raised new questions on the system's fragility and potential contagion.

Increased freedom of operation due to liberalization and deregulation has therefore also resulted in increasing attention for monitoring and supervision. Market indicators of financial risk play an increasingly important role in this respect due to their real-time availability and their efficient reflection of all available information. The market for credit default swaps has started to take a central place as it provides an efficient way to transfer and price credit risk. Moreover, CDS spreads provide a direct and easy measure of an individual bank's credit risk. Assuming that the CDS market appropriately prices each bank's riskiness into the CDS spreads, differences between banks may arise from two sources. On the one hand, a bank's risk level may be affected by a common (market) shock differently from other banks due to different underlying characteristics. On the other hand a bank's risk level may change due to "own" shocks that do not influence the market as a whole. 
In this paper, I have focused on the development and determinants of CDS spreads for 18 major European banks between December 2001 and January 2004 using daily data. More particularly, spreads are decomposed into two common factors and a remaining group of (stationary) idiosyncratic determinants. I have demonstrated that two nonstationary common factors can be extracted from the data that together explain most CDS spread variation across time and across banks. The group of German banks plus a few Southern-European banks appear to systematically have high CDS spreads and to be relatively sensitive to changes in the underlying factors. The dominating first common factor impacts on all banks in a similar direction, suggesting strong market integration. However, the quantitatively less important second factor has opposite effects on credit spreads of Southern European versus Northern European banks, suggesting some remaining country-specific or region-specific credit risk. Finally, I show that the first common factor may indeed be interpreted as a measure of market conditions as it is cointegrated with the European $\mathrm{P} / \mathrm{E}$ ratio and the 2-year nominal interest rate.

In my view, the results of this first exploratory analysis of the data yield interesting and promising results. Some questions remain for future research, however. Most importantly, I have paid no attention as yet to individual bank characteristics, such as ratings, leverage, stock return volatility etc that have been shown to play a role in the pricing of credit risk in related research. Possibly, differences in these characteristics across banks may explain their differential sensitivity to the common market shock - that in turn reflect overall European stock and bond market developments. Also, further analysis in this direction may shed additional light on the determinants of the second common factor that appears to differentiate between Southern and Northern European banks. Finally, extending the dataset both with respect to the number of banks and the sample period considered is important to determine the robustness of the current results. 


\section{Reference List}

- Berger A. N., Davies S.M. and M.J. Flannery (2000), Comparing Market and Supervisory Assessments of Bank Performance: Who Knows What When?, Journal of Money, Credit and Banking, 32, pp.642-670.

- Birchler, U. W. and D. Hancock, What Does the Yield on Subordinated Bank Debt Measure?, Finance and Economics Discussion Series 2004-19, Federal Reserve Board, Washington DC.

- Blanco, R., Brennan S. and I.W. Marsh (2004), An empirical analysis of the dynamic relationship between investment grade bonds and credit default swaps, working paper.

- $\quad$ Aunon-Nerin D., D. Cossin, T. Hricko and Z. Huang (2002), Exploring for the Determinants of Credit Risk in Credit Default Swap Transaction Data: Is Fixed-Income Markets' Information Sufficient to Evaluate Credit Risk?, Research Paper no. 65, FAME.

- Cossin, D. and H. Lu (2004), Are European Corporate Bond and Default Swap Markets Segmented?, working paper no. 133, Swiss Finance Institute.

- DeYoung, R., Flannery M.J., Lang, W.W. and S.M. Sorescu (2001), The Information Context of Bank Exam Ratings and Subordinated Debt Prices, Journal of Money, Credit and Banking, 33, pp. 901-925.

- Elton, E.J., M. J. Gruber, D. Agrawal, and C. Mann (2001), Explaining the Rate Spread on Corporate Bonds, Journal of Finance, 56, pp. 247-277.

- Flannery, M. J.(1998), Using Market Information in Prudential Bank Supervision: a Review of the US Empirical Evidence, Journal of Money, Credit and Banking, 30., pp. 273-305.

- Flannery, M.J. and S.M. Sorescu (1996), Evidence of Bank Market Discipline in Subordinated Debenture Yields: 1983-1991, The Journal of Finance, 51, pp.1347-1377.

- Gilbert, R.A. (1990), Market Discipline of Bank Risk: Theory and Evidence, Federal Reserve Bank of St. Louis Review, 72, pp. 3-18.

- Gonzalo, J. and C. Granger (1995), Estimation of Common Long-Memory Components in Cointegrated Systems, Journal of Business \& Economic Statistics, 13, pp. 27-35.

- Granger, C. and N. Haldrup (1997), Separation in Cointegrated Systems and PersistentTransitory Decompositions", Oxford Bulletin of Economics and Statistics, 59, pp. 449-463.

- Gropp, R., Vesala, J and G Vulpes (2002), Equity and bond market signals as leading indicators of bank fragility, ECB Working Paper No 150, European Central Bank.

- Hartmann P. and O. de Brandt (2000), Systemic Risk: A Survey, ECB working paper no. 35.

- Hancock D. and M.L. Kwast (2001), Using Subordinated Debt to Monitor Bank Holding Companies: Is It feasible?, Journal of Financial Services Research, 20, pp. 147-187. 
- Houweling P. and T. Vorst (2001), An Empirical Comparison of Default Swap Pricing Models, working paper.

- Holmes, M.J., "Principal Components, Stationary, and New Evidences of Purchasing Power Parity in Developing Countries", 2001

- Hull, J., Predescu, M. and A. White (2004), The Relationship Between Credit Default Swap Spreads, Bond Yields, and Credit Rating Announcements, Journal of Banking and Finance, 28, pp. 2789-2811.

- Krainer, J. and J.A. Lopez (2002), Incorporating Equity Market Information into Supervisory Monitoring Models, working paper 2001-14, Federal Reserve Bank of San Francisco.

- $\quad$ Longstaff, F.A., Mithal, S. and E. Neis (2004), Corporate Yield Spreads: Default Risk or Liquidity? New Evidence from the Credit-Default Swap Market (previously titled: The Credit-Default Swap Market: Is Credit Protection Priced Correctly?), working paper 11'03, Anderson Graduate School of Management, UCLA (forthcoming Journal of Finance).

- Padoa-Schioppa, T. (2003), Central Banks and Financial Stability: Exploring a Land in Between, European Central Bank.

- Norden, L. and M. Weber (2004), The Comovement of Credit Default Swap, Bond and Stock Markets: An Empirical Analysis, Discussion Paper Series no. 4674, CEPR.

- Stock, J.H. and M.W. Watson (1988), Testing for Common Trends, Journal of the American Statistical Association, 83, pp. 1097-1107.

- Swidler, S. and J.A. Wilcox (2002), Information about Bank Risk in Option Prices, Journal of Banking and Finance, 26, pp. 1033-1057.

- Zhu, H. (2004), An Empirical Comparison of Credit Spreads Between the Bond Market and the Credit Default Swap Market, BIS Working Paper no. 160. 
Table 1: Banks and their relative market position

\begin{tabular}{|l|l|l|l|}
\hline Name & Country & $\begin{array}{l}\text { European rank } \\
\text { (total assets) }\end{array}$ & $\begin{array}{l}\text { National rank (total } \\
\text { assets) }\end{array}$ \\
\hline UBS AG & Switzerland & 1 & 1 \\
\hline DEUTSCHE BANK AG & Germany & 2 & 1 \\
\hline BNP PARIBAS SA & France & 3 & 1 \\
\hline BAYERISCHE HYPO-UND VEREINSBANK AG & Germany & 4 & 2 \\
\hline BARCLAYS BANK PLC & United Kingdom & 5 & 1 \\
\hline ABN AMRO BANK NV & Netherlands & 6 & 1 \\
\hline SOCIETE GENERALE & France & 7 & 4 \\
\hline ING BANK NV & Netherlands & 8 & 2 \\
\hline COMMERZBANK AG & Germany & 9 & 3 \\
\hline DRESDNER BANK AG & Germany & 10 & 4 \\
\hline LLOYDS TSB BANK PLC & United Kingdom & 15 & 4 \\
\hline BANCO SANTANDER CENTRAL HISPANO SA & Spain & 16 & 1 \\
\hline INTESABCI SPA & Italy & 18 & 1 \\
\hline BANCO BILBAO VIZCAYA ARGENTARIA SA & Spain & 21 & 2 \\
\hline CREDIT LYONNAIS & France & 24 & 8 \\
\hline UNICREDITO ITALIANO SPA & Italy & 32 & 2 \\
\hline SANPAOLO IMI SPA & Italy & 35 & 3 \\
\hline ABBEY NATIONAL PLC & United Kingdom & 41 & 6 \\
\hline
\end{tabular}

Source: Bankscope, 2004 
Table 2: Stylised Statistics on CDS Spreads

\begin{tabular}{|c|c|c|c|c|}
\hline Bank & Mean & Std. Dev. & Min. & Max. \\
\hline \multicolumn{5}{|c|}{ Panel A: CDS Spreads (levels, in basis points) } \\
\hline Abbey Nat'1 & 46.71 & 17.69 & 23.50 & 102.50 \\
\hline ABN AMRO & 47.76 & 20.76 & 23.50 & 120.00 \\
\hline Barclays & 35.85 & 11.31 & 18.50 & 65.00 \\
\hline Bayer Hypo & 136.02 & 75.90 & 50.50 & 330.00 \\
\hline BBVA & 49.97 & 23.59 & 20.00 & 145.00 \\
\hline BNP Paribas & 39.70 & 14.64 & 20.50 & 95.00 \\
\hline $\mathrm{BSCH}$ & 84.72 & 56.49 & 24.50 & 290.00 \\
\hline Commerz & 135.99 & 88.12 & 45.00 & 475.00 \\
\hline Credit Lyonn & 44.40 & 17.00 & 20.00 & 120.00 \\
\hline Deutsche & 54.81 & 25.42 & 25.50 & 15750 \\
\hline Dresdner & 78.00 & 43.64 & 28.00 & 200.00 \\
\hline ING & 44.55 & 14.35 & 24.50 & 85.00 \\
\hline Intesa & 68.14 & 35.49 & 30.50 & 195.00 \\
\hline Lloyds TSB & 35.31 & 11.36 & 21.00 & 72.50 \\
\hline San Paolo & 45.15 & 14.46 & 22.50 & 95.00 \\
\hline Soc Gen & 42.24 & 16.55 & 22.50 & 100.00 \\
\hline UBS & 33.98 & 12.38 & 16.00 & 72.50 \\
\hline Unicredito & 43.43 & 14.25 & 20.00 & 82.50 \\
\hline \multicolumn{5}{|c|}{ Panel B: CDS Spreads (first differences, in basis points) } \\
\hline Abbey Nat'l & -0.02 & 2.75 & -12.50 & 25.00 \\
\hline ABN AMRO & -0.06 & 2.89 & -17.50 & 22.50 \\
\hline Barclays & -0.01 & 1.61 & -8.00 & 16.50 \\
\hline Bayer Hypo & 0.07 & 10.10 & -95.00 & 50.00 \\
\hline BBVA & -0.06 & 3.72 & -42.50 & 32.50 \\
\hline BNP Paribas & -0.03 & 2.21 & -12.50 & 20.00 \\
\hline $\mathrm{BSCH}$ & -0.09 & 5.37 & -32.50 & 37.50 \\
\hline Commerz & 0.02 & 10.78 & -85.00 & 70.00 \\
\hline Credit Lyonn & -0.03 & 2.67 & -15.00 & 25.00 \\
\hline Deutsche & -0.02 & 3.30 & -22.50 & 32.50 \\
\hline Dresdner & 0.04 & 5.11 & -25.00 & 32.50 \\
\hline ING & -0.03 & 2.35 & -20.00 & 27.00 \\
\hline Intesa & -0.06 & 5.05 & -27.50 & 35.00 \\
\hline Lloyds TSB & -0.00 & 2.07 & -14.50 & 17.50 \\
\hline San Paolo & -0.03 & 2.04 & -15.00 & 15.00 \\
\hline Soc Gen & -0.03 & 2.10 & -9.50 & 22.50 \\
\hline UBS & -0.02 & 1.86 & -15.00 & 15.00 \\
\hline Unicredito & -0.05 & 2.34 & -12.50 & 20.00 \\
\hline
\end{tabular}


Table 3: Level Regressions (common sample)

\begin{tabular}{|c|c|c|c|c|}
\hline Bank & Intercept & Factor1 & Factor2 & Adj R2 \\
\hline Abbey Nat'l & $\begin{array}{l}46.71 \\
(0.22) \\
\end{array}$ & $\begin{array}{c}17.14 \\
(0.25) \\
\end{array}$ & $\begin{array}{c}4.23 \\
(0.28) \\
\end{array}$ & 0.917 \\
\hline ABN AMRO & $\begin{array}{l}47.76 \\
(0.20)\end{array}$ & $\begin{array}{l}18.80 \\
(0.29)\end{array}$ & $\begin{array}{l}-4.88 \\
(0.27)\end{array}$ & 0.948 \\
\hline Barclays & $\begin{array}{l}35.85 \\
(0.12)\end{array}$ & $\begin{array}{l}11.07 \\
(0.12)\end{array}$ & $\begin{array}{c}0.71 \\
(0.12)\end{array}$ & 0.940 \\
\hline Bayer Hypo & $\begin{array}{c}136.02 \\
(0.68)\end{array}$ & $\begin{array}{l}63.98 \\
(0.89)\end{array}$ & $\begin{array}{l}50.18 \\
(0.83)\end{array}$ & 0.957 \\
\hline BBVA & $\begin{array}{l}49.97 \\
(0.20)\end{array}$ & $\begin{array}{l}19.82 \\
(0.37)\end{array}$ & $\begin{array}{l}-9.03 \\
(0.22)\end{array}$ & 0.962 \\
\hline BNP Paribas & $\begin{array}{l}39.70 \\
(0.11)\end{array}$ & $\begin{array}{l}13.70 \\
(0.15)\end{array}$ & $\begin{array}{l}-2.69 \\
(0.16)\end{array}$ & 0.969 \\
\hline$\overline{\mathrm{BSCH}}$ & $\begin{array}{l}84.72 \\
(0.60)\end{array}$ & $\begin{array}{l}50.09 \\
(0.83)\end{array}$ & $\begin{array}{r}-15.27 \\
(0.70)\end{array}$ & 0.941 \\
\hline Commerz & $\begin{array}{c}135.99 \\
(0.66)\end{array}$ & $\begin{array}{c}82.92 \\
(1.19)\end{array}$ & $\begin{array}{l}43.53 \\
(0.77) \\
\end{array}$ & 0.970 \\
\hline Credit Lyonn & $\begin{array}{l}44.40 \\
(0.18)\end{array}$ & $\begin{array}{l}14.71 \\
(0.30)\end{array}$ & $\begin{array}{l}-5.29 \\
(0.20)\end{array}$ & 0.937 \\
\hline Deutsche & $\begin{array}{l}54.81 \\
(0.25)\end{array}$ & $\begin{array}{l}25.05 \\
(0.40)\end{array}$ & $\begin{array}{c}2.31 \\
(0.28)\end{array}$ & 0.948 \\
\hline Dresdner & $\begin{array}{l}78.00 \\
(0.42)\end{array}$ & $\begin{array}{l}38.22 \\
(0.54)\end{array}$ & $\begin{array}{l}26.36 \\
(0.54)\end{array}$ & 0.951 \\
\hline$\overline{\mathrm{ING}}$ & $\begin{array}{l}44.55 \\
(0.15)\end{array}$ & $\begin{array}{l}14.09 \\
(0.25) \\
\end{array}$ & $\begin{array}{c}1.74 \\
(0.23)\end{array}$ & 0.938 \\
\hline Intesa & $\begin{array}{l}68.14 \\
(0.49)\end{array}$ & $\begin{array}{l}33.42 \\
(0.72)\end{array}$ & $\begin{array}{l}-1.16 \\
(0.63)\end{array}$ & 0.898 \\
\hline Lloyds TSB & $\begin{array}{l}35.31 \\
(0.16)\end{array}$ & $\begin{array}{l}10.82 \\
(0.25)\end{array}$ & $\begin{array}{c}0.42 \\
(0.21)\end{array}$ & 0.897 \\
\hline San Paolo & $\begin{array}{l}45.15 \\
(0.18)\end{array}$ & $\begin{array}{l}13.18 \\
(0.24)\end{array}$ & $\begin{array}{l}-2.52 \\
(0.20)\end{array}$ & 0.914 \\
\hline Soc Gen & $\begin{array}{l}42.24 \\
(0.11)\end{array}$ & $\begin{array}{l}15.26 \\
(0.16)\end{array}$ & $\begin{array}{l}-3.80 \\
(0.15)\end{array}$ & 0.975 \\
\hline UBS & $\begin{array}{l}33.98 \\
(0.13)\end{array}$ & $\begin{array}{l}11.56 \\
(0.14)\end{array}$ & $\begin{array}{l}-1.91 \\
(0.15)\end{array}$ & 0.945 \\
\hline Unicredito & $\begin{array}{l}43.43 \\
(0.20)\end{array}$ & $\begin{array}{l}12.33 \\
(0.21)\end{array}$ & $\begin{array}{l}-3.74 \\
(0.22)\end{array}$ & 0.894 \\
\hline
\end{tabular}


Table 4: First Difference (ECM) Regressions (common sample)

\begin{tabular}{|c|c|c|c|c|c|c|c|}
\hline Bank & Intercept & $D(F 1)$ & $D(F 2)$ & ECM & $F 1(-1)$ & $F 2(-1)$ & Adj R2 \\
\hline $\begin{array}{l}\text { Abbey } \\
\text { Nat'l }\end{array}$ & $\begin{array}{c}4.39 \\
(1.52)\end{array}$ & $\begin{array}{l}17.71 \\
(2.72)\end{array}$ & $\begin{array}{c}3.21 \\
(1.61)\end{array}$ & $\begin{array}{l}-0.094 \\
(0.03)\end{array}$ & $\begin{array}{c}17.14 \\
(1.56)\end{array}$ & $\begin{array}{c}4.72 \\
(1.18)\end{array}$ & 0.389 \\
\hline $\begin{array}{l}\text { ABN } \\
\text { AMRO }\end{array}$ & $\begin{array}{c}4.98 \\
(1.78)\end{array}$ & $\begin{array}{l}20.74 \\
(3.69)\end{array}$ & $\begin{array}{l}-7.62 \\
(1.84)\end{array}$ & $\begin{array}{l}-0.104 \\
(0.04)\end{array}$ & $\begin{array}{l}18.26 \\
(1.53)\end{array}$ & $\begin{array}{l}-4.74 \\
(1.03)\end{array}$ & 0.511 \\
\hline Barclays & $\begin{array}{c}3.60 \\
(0.96) \\
\end{array}$ & $\begin{array}{l}11.70 \\
(1.39\end{array}$ & $\begin{array}{l}-2.44 \\
(0.96) \\
\end{array}$ & $\begin{array}{l}-0.100 \\
(0.03) \\
\end{array}$ & $\begin{array}{c}11.25 \\
(0.70) \\
\end{array}$ & $\begin{array}{c}1.00 \\
(0.48)\end{array}$ & 0.481 \\
\hline $\begin{array}{l}\text { Bayer } \\
\text { Hypo }\end{array}$ & $\begin{array}{l}11.88 \\
(3.66)\end{array}$ & $\begin{array}{l}71.09 \\
(7.45)\end{array}$ & $\begin{array}{l}41.25 \\
(6.20)\end{array}$ & $\begin{array}{r}-0.087 \\
(0.03)\end{array}$ & $\begin{array}{l}62.28 \\
(5.29)\end{array}$ & $\begin{array}{l}51.04 \\
(3.49)\end{array}$ & 0.631 \\
\hline BBVA & $\begin{array}{c}8.56 \\
(3.08) \\
\end{array}$ & $\begin{array}{l}24.65 \\
(3.86)\end{array}$ & $\begin{array}{l}-10.99 \\
(2.23) \\
\end{array}$ & $\begin{array}{l}-0.171 \\
(0.06) \\
\end{array}$ & $\begin{array}{l}19.94 \\
(1.21)\end{array}$ & $\begin{array}{l}-8.49 \\
(0.79) \\
\end{array}$ & 0.530 \\
\hline $\begin{array}{l}\text { BNP } \\
\text { Paribas }\end{array}$ & $\begin{array}{c}9.35 \\
(2.52)\end{array}$ & $\begin{array}{l}13.35 \\
(1.92)\end{array}$ & $\begin{array}{l}-4.24 \\
(1.68)\end{array}$ & $\begin{array}{c}-0.236 \\
(0.06)\end{array}$ & $\begin{array}{l}13.85 \\
(0.55)\end{array}$ & $\begin{array}{l}-2.57 \\
(0.35)\end{array}$ & 0.433 \\
\hline $\mathrm{BSCH}$ & $\begin{array}{c}3.43 \\
(2.31)\end{array}$ & $\begin{array}{l}27.26 \\
(5.02)\end{array}$ & $\begin{array}{l}-10.54 \\
(3.18)\end{array}$ & $\begin{array}{l}-0.041 \\
(0.03)\end{array}$ & $\begin{array}{l}42.48 \\
(7.22)\end{array}$ & $\begin{array}{l}-28.67 \\
(10.20)\end{array}$ & 0.287 \\
\hline Commerz & $\begin{array}{l}14.36 \\
(7.92) \\
\end{array}$ & $\begin{array}{l}66.42 \\
(8.29) \\
\end{array}$ & $\begin{array}{l}43.21 \\
(5.88) \\
\end{array}$ & $\begin{array}{c}-0.106 \\
(0.06) \\
\end{array}$ & $\begin{array}{l}80.75 \\
(4.79) \\
\end{array}$ & $\begin{array}{l}40.37 \\
(4.57) \\
\end{array}$ & 0.534 \\
\hline $\begin{array}{l}\text { Credit } \\
\text { Lyonn }\end{array}$ & $\begin{array}{c}6.10 \\
(1.74)\end{array}$ & $\begin{array}{c}14.26 \\
(1.75)\end{array}$ & $\begin{array}{l}-3.21 \\
(2.08)\end{array}$ & $\begin{array}{l}-0.137 \\
(0.04)\end{array}$ & $\begin{array}{l}14.99 \\
(1.66)\end{array}$ & $\begin{array}{l}-5.17 \\
(0.63)\end{array}$ & 0.337 \\
\hline Deutsche & $\begin{array}{c}4.85 \\
(1.31) \\
\end{array}$ & $\begin{array}{l}23.39 \\
(2.93) \\
\end{array}$ & $\begin{array}{c}5.22 \\
(1.67) \\
\end{array}$ & $\begin{array}{l}-0.088 \\
(0.02) \\
\end{array}$ & $\begin{array}{l}23.67 \\
(1.96)\end{array}$ & $\begin{array}{c}1.88 \\
(1.67) \\
\end{array}$ & 0.458 \\
\hline Dresdner & $\begin{array}{c}4.27 \\
(1.17) \\
\end{array}$ & $\begin{array}{l}40.53 \\
(3.02) \\
\end{array}$ & $\begin{array}{l}14.96 \\
(3.16) \\
\end{array}$ & $\begin{array}{l}-0.054 \\
(0.01) \\
\end{array}$ & $\begin{array}{l}39.82 \\
(3.84) \\
\end{array}$ & $\begin{array}{l}27.17 \\
(3.14) \\
\end{array}$ & 0.653 \\
\hline ING & $\begin{array}{c}5.49 \\
(1.88)\end{array}$ & $\begin{array}{l}15.77 \\
(3.26)\end{array}$ & $\begin{array}{l}-0.35 \\
(1.17)\end{array}$ & $\begin{array}{l}-0.123 \\
(0.04)\end{array}$ & $\begin{array}{l}14.42 \\
(0.98)\end{array}$ & $\begin{array}{c}1.78 \\
(0.95)\end{array}$ & 0.428 \\
\hline Intesa & $\begin{array}{c}3.96 \\
(1.71) \\
\end{array}$ & $\begin{array}{l}33.62 \\
(3.37) \\
\end{array}$ & $\begin{array}{c}9.95 \\
(2.17) \\
\end{array}$ & $\begin{array}{l}-0.059 \\
(0.03)\end{array}$ & $\begin{array}{l}33.72 \\
(5.11)\end{array}$ & $\begin{array}{l}-2.06 \\
(2.87)\end{array}$ & 0.479 \\
\hline $\begin{array}{l}\text { Lloyds } \\
\text { TSB }\end{array}$ & $\begin{array}{c}4.47 \\
(0.94)\end{array}$ & $\begin{array}{c}9.98 \\
(1.27)\end{array}$ & $\begin{array}{l}-0.49 \\
(1.09)\end{array}$ & $\begin{array}{l}-0.126 \\
(0.03)\end{array}$ & $\begin{array}{l}11.04 \\
(0.84)\end{array}$ & $\begin{array}{c}0.25 \\
(0.84)\end{array}$ & 0.259 \\
\hline San Paolo & $\begin{array}{c}2.78 \\
(0.99)\end{array}$ & $\begin{array}{c}13.84 \\
(1.54)\end{array}$ & $\begin{array}{c}2.43 \\
(1.24)\end{array}$ & $\begin{array}{r}-0.062 \\
(0.02)\end{array}$ & $\begin{array}{l}13.08 \\
(2.06)\end{array}$ & $\begin{array}{l}-1.98 \\
(1.10)\end{array}$ & 0.451 \\
\hline Soc Gen & $\begin{array}{c}7.33 \\
(1.72) \\
\end{array}$ & $\begin{array}{l}14.64 \\
(2.21) \\
\end{array}$ & $\begin{array}{l}-3.83 \\
(1.01) \\
\end{array}$ & $\begin{array}{l}-0.173 \\
(0.04) \\
\end{array}$ & $\begin{array}{l}15.30 \\
(0.56) \\
\end{array}$ & $\begin{array}{l}-3.81 \\
(0.47) \\
\end{array}$ & 0.507 \\
\hline UBS & $\begin{array}{c}5.24 \\
(1.38)\end{array}$ & $\begin{array}{c}9.51 \\
(1.93) \\
\end{array}$ & $\begin{array}{l}-2.05 \\
(1.31)\end{array}$ & $\begin{array}{l}-0.154 \\
(0.04)\end{array}$ & $\begin{array}{l}11.58 \\
(0.60)\end{array}$ & $\begin{array}{l}-2.25 \\
(0.68)\end{array}$ & 0.293 \\
\hline Unicredito & $\begin{array}{l}2.983 \\
(0.89)\end{array}$ & $\begin{array}{l}15.91 \\
(2.22)\end{array}$ & $\begin{array}{l}-1.47 \\
(1.14)\end{array}$ & $\begin{array}{l}-0.069 \\
(0.02)\end{array}$ & $\begin{array}{c}12.83 \\
(1.64)\end{array}$ & $\begin{array}{l}-2.81 \\
(1.34)\end{array}$ & 0.434 \\
\hline
\end{tabular}


Figure 1 CDS Spreads per Country
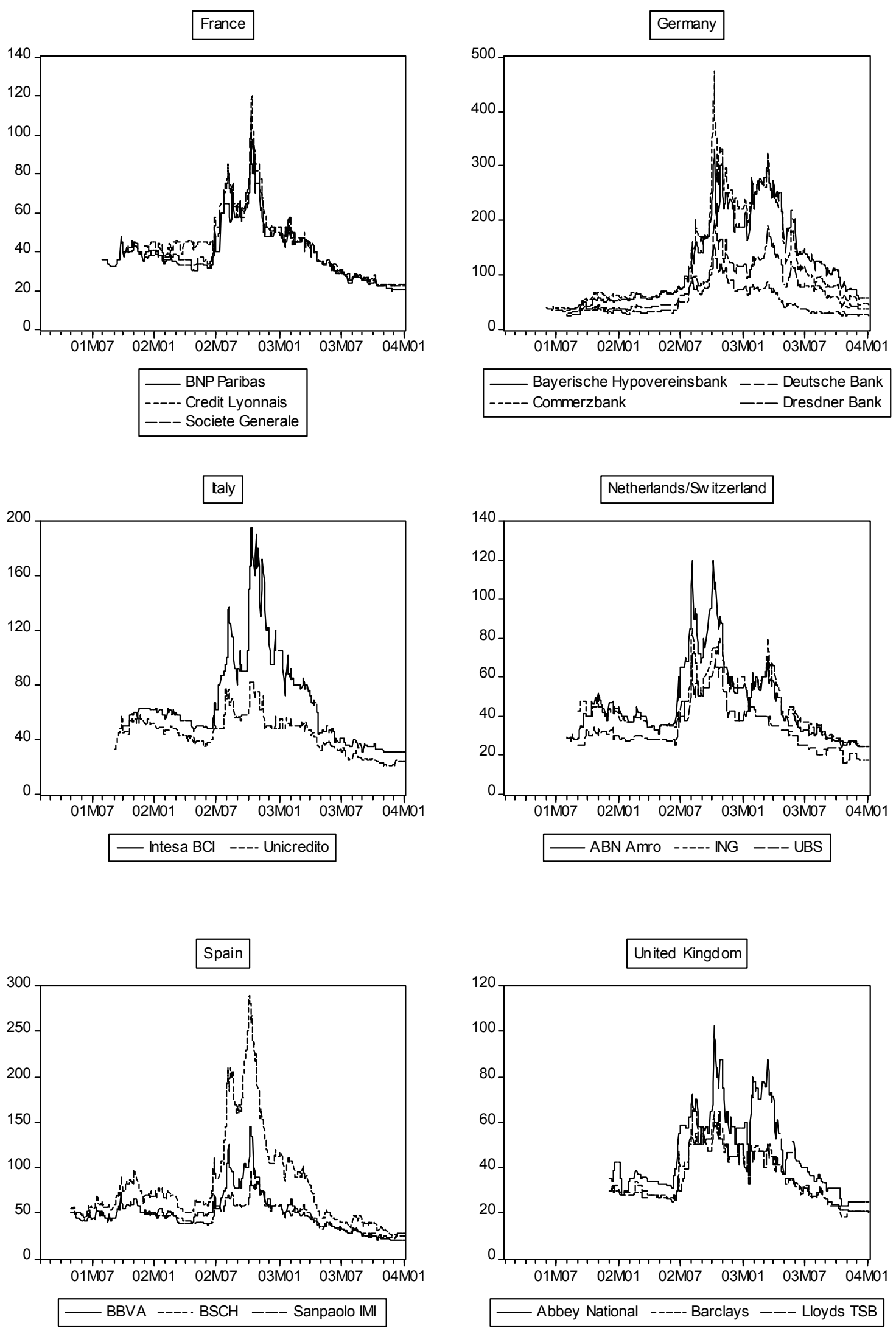
Figure 2 Common Factors

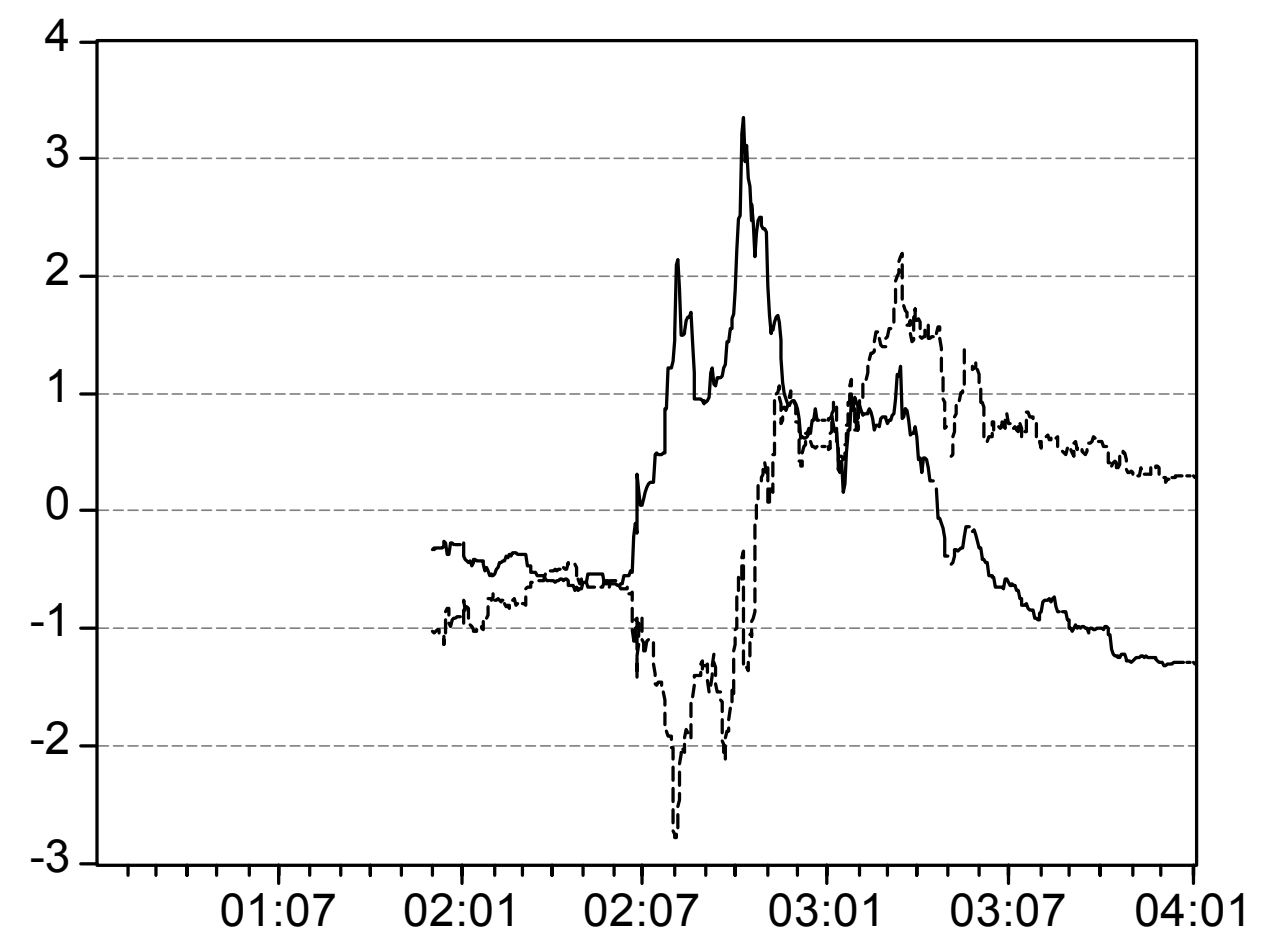

FIRST COMMON FACTOR ---- SECOND COMMON FACTOR 